\title{
An Empirical Study of the Antecedents and Consequences of Innovativeness
}

\author{
Mohammad Ziaul Hoq ${ }^{\star}$ and AHM Ehsanul Huda Chowdhury ${ }^{* \star}$ \\ In this study, we address two research questions: (1) Why are \\ some SMEs (Small Medium Enterprise) more innovative than \\ others? (2) What effect does innovativeness has on business \\ performance? Accordingly, we draw on various theoretical \\ perspectives to develop hypotheses that propose social capital \\ orientation and market orientation as key antecedents to \\ innovativeness, as well as a direct relationship between \\ innovativeness and business performance. A model is devised and \\ tested that examines these relationships in general. Findings \\ confirm the validity of the model. Lastly, implications are offered on \\ the antecedents and consequences of organizational \\ innovativeness
}

JEL Codes: F34, G21 and G24

\section{Introduction}

The purpose of this study was to develop a theory related to the functioning of SME and to identify factors contributing to the growth of SMEs since very little has been done in this area (Cook, 2001; Gadenne, 1997; Wijewardena \& Tibbits, 1999). The study was limited to the small and medium scale business units. The small and medium businesses were defined as those (Geraldo, 1992), which had an investment between $\$ 0.5$ to $\$ 1.5$ million in accordance with the definition of World Bank and Government of Bangladesh.

Small Medium Enterprises (SMEs) are perceived as vulnerable yet valuable entities, important both economically and socially (McCaran-Quinn and Carson, 2003). They are recognized as engines of economic growth. The growing economic significance of the SMEs as sources of new business creation and employment generation in the developed, OECD countries especially since 1970 s is now widely recognized in an increasingly growing volume of literature (OECD, 1997). It is widely recognised today, that SMEs represent the backbone of the local economies in Europe. SMEs contribute to more than two-thirds of employment (70.2 per cent) and turnover (70.3 per cent) in the European Union and between 65 to 85 per cent of the total value added (European Commission, 1993a). Growing recognition of the economic contribution of SMEs has given rise to a large number of activities in many international organizations, both governmental and nongovernmental (OECD, 2000).

While firms in less developed countries, in the recent past, were operating within a relatively protected environment, they must now face the global forces of competition. The globalization of the markets requires the adaptation of firms in order to survive. Even small firms have to introduce new products of higher quality and take advantage of new

\footnotetext{
* Dr. Mohammad Ziaul Hoq, Co-op Coordinator (In charge), Department of MIT, Jubail Industrial College, Royal Commission of Jubail, Kingdom of Saudi Arabia, Email: mohammad_z@jic.edu.sa.

"Dr. AHM Ehsanul Huda Chowdhury, Associate Dean \& Associate Professor, Faculty of Business Administration, American International University- Bangladesh (AIUB), Email: ehsanul@aiub.edu.
} 


\section{Hoq \& Chowdhury}

technology. Innovation is a difficult undertaking, especially for firms with little experience and limited resources.

Small firms in less developed countries have to face in addition to the liability of their size, the limitations of an inadequate infrastructure. The study of innovation, including the obstacles to its successful implementation, while relatively well researched in the industrialized countries is rather neglected in less developed countries (Bell and Pavitt, 1992).

Encouraging innovation in small and medium sized enterprises (SMEs) remains at the heart of policy initiatives for stimulating economic development at the local, regional, national and international levels (Jones and Tilley, 2003). At a theoretical level, innovation has also replaced efficiency as the crucial focus of much theory building and policy analysis with efficiency becoming a necessary adjunct to innovation (Clark and Staunton, 1989). Yet, despite increasing attention being given to the role of SMEs and innovation there is a hiatus between what is understood by way of the general innovation literature and the extant literature on innovation in SMEs. Although there is the absence of a common theoretical basis for innovation research more generally (Drazin and Schoonhoven, 1996) it is apparent that, notwithstanding this, studies of innovation in SMEs have largely failed to reflect advances in the innovation literature. This failure to improve our basic understanding of innovation in SMEs is disappointing given that, in the UK, SMEs (including sole traders) amount for $99 \%$ of businesses, $55 \%$ of nongovernmental employment and $51 \%$ of turnover (SBS, 2001).

It is well accepted that a strong SME will result in a competitive edge for an economy (Day, 2000). Reynolds, (1997) indicates that EU countries' employment, value added and sales by firm size for the SMEs have increased on all measures of economic activity; and many large organizations have experienced substantial losses. Wang and Yao, (2002) show the SMEs in Korea reflect a much greater share in employment. Similar episodes are prevalent in China; during 1995-2000, small enterprises accounted for $62.5 \%$ of total industrial output and 73.6\% of its industrial employment (Wang and Yao, 2002).

Our main contention is that a revision of existing research perspectives is not only theoretically overdue in the context of SMEs it is of practical relevance, given the continued focus of public policy and money on improving the innovative potential of SMEs, particularly in developing countries like Bangladesh.

A key component in the success of SMEs is the extent of their innovativeness. Innovativeness relates to the firm's capacity to engage in innovation; that is, the introduction of new processes, products, or ideas in the organization. This capacity to innovate is among the most important factors that impact on business performance (e.g., Burns \& Stalker, 1961; Hurley, Hult, \& Tomas, 1998; Porter, 1990; Schumpeter, 1934). It is through innovativeness that managers devise solutions to business problems and challenges, which provide the basis for the survival and success of the firm well into the future. Innovativeness is one of the factors over which the management has considerable control. However, studies on the factors that give rise to innovativeness in the firm have produced mixed results (Abratt \& Lombard, 1993; Henard \& Szymanski, 2001; Poolton \& Barclay, 1998). While it is generally agreed that innovation contributes to business performance, relatively little is known about the drivers of innovativeness and how those drivers operate via innovativeness to collectively influence performance. To address these issues, a sample of 321 SMEs is investigated to determine (1) the effect of two key organizational orientations posited from the literature on innovativeness, (2) the 


\section{Hoq \& Chowdhury}

hypothesized effect of innovativeness on business performance. Findings can help the management to better understand what types of orientations should be encouraged with a view to increasing the level of innovativeness among SMEs.

Based on a review of relevant literature and theoretical conceptualizations, we will argue that among the key antecedents to innovativeness are the constructs of social capital orientation and market orientation.

Researchers have emphasized the importance of market orientation (Jaworski \& Kohli, 1993; Narver \& Slater, 1990). Similarly, research on competitive advantage has highlighted the importance of social capital orientation (Nahapiet and Ghosal, 1997). While the positional advantage of firms has been suggested to be a function of social capital orientation, market orientation, and innovativeness, no study has examined the linkages among these constructs in an integrated manner. As such, we do not know how these constructs interact to influence business performance. This study intends to shed new and important light on these constructs and the interrelationships among them. Specifically, we devise a theory-based structural equation model that links these constructs together. We then conduct a survey-based study of SMEs to evaluate the validity of linkages posited in the model.

We begin by examining how innovativeness has been related to organizational adaptation and performance in the context of relevant theoretical perspectives. Next, we assess the plausibility of social capital orientation and market orientation as antecedents to innovativeness and offer a collection of associated hypotheses. In the methods section, the study sample of 321 firms is discussed and the construct measures are evaluated. Next, the relationships among these constructs are assessed and discussed.

\section{Literature Review}

\subsection{Background and Hypotheses}

Culture reflects norms, values, and beliefs that reinforce behaviours ultimately related to business performance. When specific orientations are embedded in organizational culture, the intensity and consistency of resultant behaviours are augmented across situations, groups, and persons within the firm. A culture that supports the execution of a strategy is difficult to copy and thus can become a sustainable competitive advantage (Barney, 1986). The principal question addressed in this paper is how each of key antecedents and innovativeness are related and how they collectively enable the organization to adapt and perform. We now examine these factors in depth to highlight relationships among them and their association with business performance. The linkages proposed among the constructs investigated here are illustrated in Fig. 1.

Innovativeness is defined here as the capacity to introduce of some new process, product, or idea in the organization (Damanpour, 1991; Hurley et al., 1998). An innovation can be a new product or service, a new production process, or a new structure or administrative system. Certain types of innovations such as administrative innovations that improve internal operations may have no direct or immediate impact on the marketplace (Han, Kim, \& Srivastava, 1998). Zaltman, Duncan, and Holbek (1973) suggest that one of the stages of the innovativeness process is initiation. A critical part of the initiation stage is cultural "openness to the innovation" (Zaltman et al., 1973, p. 64). Openness includes whether the members of an organization are willing to consider the adoption of an 


\section{Hoq \& Chowdhury}

innovation or whether they are resistant to it. Van de Ven (1986) refers to this as the management of the organization's cultural attention in order to recognize the need for new ideas and action within the organization.

On the other hand, innovativeness is primarily distinguished from entrepreneurial orientation in that it does not require new market entry (Lumpkin \& Dess, 1996, p. 136). Much of the firm's innovativeness hinges on the extent to which managers acquire and act on market intelligence. Organizations that act are responsive to markets. Organizations without the capacity to innovate may invest time and resources in studying markets but are unable to translate this knowledge into practice.

Moreover, the adoption of innovation is generally intended to contribute to the performance or effectiveness of the firm (e.g., Damanpour, 1991). Business performance is defined here as the achievement of organizational goals related to profitability and growth in sales and markets share, as well as the accomplishment of general firm strategic objectives.

The resource-based view (Wernerfelt, 1984) helps to explain how firms derive competitive advantages by channelling resources into the development of new products, processes, and so forth. Innovation is a means for changing an organization, whether as a response to changes that occurs in its internal or external environment or as a pre-emptive move taken to influence an environment. Because environments evolve, firms must adopt innovations over time and the most important innovations are those that allow the firm to achieve some sort of competitive advantage, thereby contributing to its performance (e.g., Damanpour, 1991; Henard \& Szymanski, 2001; Porter, 1990). This discussion leads to our first hypothesis.

$\mathrm{H} 1$ : The degree of innovativeness is associated to the degree of business performance.

\subsection{Social Capital Orientation and Innovativeness}

Bourdieu (1983, p. 250) defines social capital in terms of resources linked to group membership, and highlights the importance of 'durable obligations subjectively felt (feelings of gratitude, respect, friendship etc.)'. Tsai and Ghoshal (1998) investigated the impact of social capital on the internal functioning of firms, focusing on the extent to which social capital facilitates a firm's ability to create value through innovations. Central to these studies is the idea that networks of relationships and interactions between individuals can facilitate the creation of value within firms. Accordingly, we anchor our hypothesized model in a resource based view of the firm in which social capital, and its constituent elements, are considered valuable, inimitable, and non-substitutable assets that underpin key processes and values - in this case innovation-that lead to competitive advantage (Wernerfelt, 1984).

However, we adopt Woodman et al.'s (1993, p. 293) characterization of organizational innovation, which is defined as the 'the creation of a valuable, useful new product, service, idea, procedure, or process by individuals working together in a complex social system'.

Moreover, we argue that open communication, trusting culture and shared vision are the key components of social capital within organizations - will improve SMEs performance. The benefits of social capital are not simply manifested in incremental improvements but also in more dramatic advances in business processes. For this reason we look at the mediating effects of innovation. 


\section{Hoq \& Chowdhury}

Open communication captures the idea of employees within organization sharing information and learning from the experience of other employees. Innovation is more likely to occur in organizations characterized by open communication (kanter, 1988). The work of Angle and his colleagues in the Minnesota Innovation Survey (see Angle, 1989) demonstrates the important influence on creativity and innovation of information flows within the organization.

In addition, the cognitive aspect of social capital, shared vision, points to the way in which members of a network are united by a common sense of purpose and by the existence of an esprit de corps. Evidence suggests co-worker support, interaction, and shared goals improve the innovative output of employees who may otherwise display limited creative behaviour (Madjar et. al., 2002; Zhou and Shalley, 2003). We favour the view that the mutual understanding and support that is intrinsic to a shared vision will tend to foster innovation. Likewise, Amabile (1998) argues that clearly specified strategic goals- a fundamental basis by which shared vision emerges -often enhances people's innovative skills.

On the other hand, the relational dimension of social capital is manifested in the degree of trust that exists among the employees. Because trust can foster joint efforts, higher levels of cooperation, and more positive attitudes (e.g., Dirks and Ferrin, 2001), the development of a trusting culture is likely to facilitate the propensity of employees to support each other. Tesluk, Farr and Klein (1997) highlight the importance of what they call 'socio-emotional support' in fostering creativity. They define this concept in terms of 'the extent that employees believe that the work environment provides the interpersonal support necessary to feel free to function innovatively' (p. 34). According to McLean (2005), this notion of socio-emotional support highlights the importance of a trusting culture among coworkers-and between employees and management-to ensure that employees are less risk averse and put forth creative ideas. Thus, by enabling people to take risks (Mayer et al., 1995) and by facilitating openness of expression (Gibb, 1961), trust can be crucial for the development of innovation.

Furthermore, past studies showed that social network positively related to performance and competitive advantages (Batjargal, 2003; Benson, 1998; Florin, Lubatkin \& Schulze, 2003; Pennings, Lee, \& Van Witteloostuijn, 1998) whilst Castilla et al. (2000); Mitsufuji (2003); Bhat (2005) uncovered positive association of social network aspects of the innovation processes. Studies focusing on the social aspects of business have demonstrated the importance of social ties or networks for innovation in both developed and developing regions (Malecki, 1997; Mytelka, 1993; Powell, 1990; Storper \& Salais, 1997).

The contribution of social capital to innovation is achieved by reducing transaction costs between firms and other actors, notably search and information costs, bargaining and decision costs, and policing and enforcement costs (Maskell, 2001). It has been widely acknowledged by researchers that this type of social capital would encourage cooperative behaviour, thereby facilitating the development of new form of association and innovativeness.

In addition, social capital can be observed as the network that connects businesses, and thus it facilitates business to perform well and to achieve competitive advantages ( Batjargal, 2003; Benson, 1998; Florin, Lubatkin \& Schulze, 2003; Pennings, Lee \& Van Witteloostuijn, 1998). 


\section{Hoq \& Chowdhury}

Thus, we hypothesize,

$\mathrm{H} 2$ : The extent of social capital orientation is associated to the extent of innovativeness.

\subsection{Market Orientation and Innovativeness}

Kohli and Jaworski (1993) define market orientation as a set of ongoing behaviours and activities related to generation, dissemination, and responsiveness to market intelligence. To some degree, this position is shared by Day (1994) who views market orientation as ongoing behaviours or processes via market sensing and buyer linking. Han et al. (1998, p. 31) state, "market orientation, as a corporate culture, characterizes an organization's disposition to deliver superior value to its customers continuously." Fritz (1996) found that market orientation is important for corporate success. We argue that in market-oriented organizations, behaving or introducing a process that inhibits a market focus would feel wrong and would most likely result in some censure; that is, it would be "counter cultural." Thus, market orientation is an aspect of culture and is a latent construct whose indicators are values, beliefs, and symbols that demonstrate a concern for markets. Narver and Slater (1990) emphasize that market orientation refers to a culture that places a high priority on creating buyer value while considering other stakeholders and emphasizing responsiveness to market information. Day's (1994) conceptualization holds that marketoriented companies have processes for collecting market intelligence and integrating them with strategic decision-making processes. He suggests that market intelligence comes from outside-in processes that link with spanning processes (e.g., strategic planning), which facilitate integration and implementation. These constellations of behaviours, practices, and routines form behavioural syndromes in the organization defined as culture.

While many scholars include responsiveness to markets as a part of market orientation (e.g., Kohli \& Jaworski, 1990), it can be argued that translating market intelligence into action is part of a larger planning and decision-making process that affects even internally oriented changes. Industrial firms with a market orientation are likely to devise and adapt products, services, and processes that continue to meet the needs of the evolving market. Accordingly, it is likely that innovative processes naturally flow out of a focus on being market oriented. Consistent with this view, Jaworski and Kohli (1993, p. 56) have argued that "a market orientation essentially involves doing something new or different in response to market conditions, it may be viewed as a form of innovative behaviour." Innovativeness is an important managerial function because it has been consistently linked to business performance. With the exception of work by Han et al. (1998) and Hurley et al. (1998), extant literature has not yet addressed the issue of how market orientation and innovativeness operate together to affect company performance. Arguably, a market orientation is incomplete if practitioners do not understand the modus operandi that gives rise to creating superior buyer value.

Moreover, Slater and Narver (1994b) view innovativeness as one of the core valuecreating capabilities that drives the market orientation- performance relationship. In their seminal work, Zaltman et al. (1973) propose that innovativeness is the medium for business success in the wake of appropriate intelligence gathering and decision making (cf. Hurley et al., 1998). Much later, Deshpande, Farley, and Webster (1993) speculated on a strong linkage between market orientation and innovativeness for achieving superior business performance outcomes. Most recently, Henard and Szymanski (2001) highlighted empirical work that suggests that market orientation contributes to new product success. Accordingly, we hypothesize, 


\section{Hoq \& Chowdhury}

H3: The scale of market orientation is associated to the scale of innovativeness.

Fig. 1: Hypothesized Model

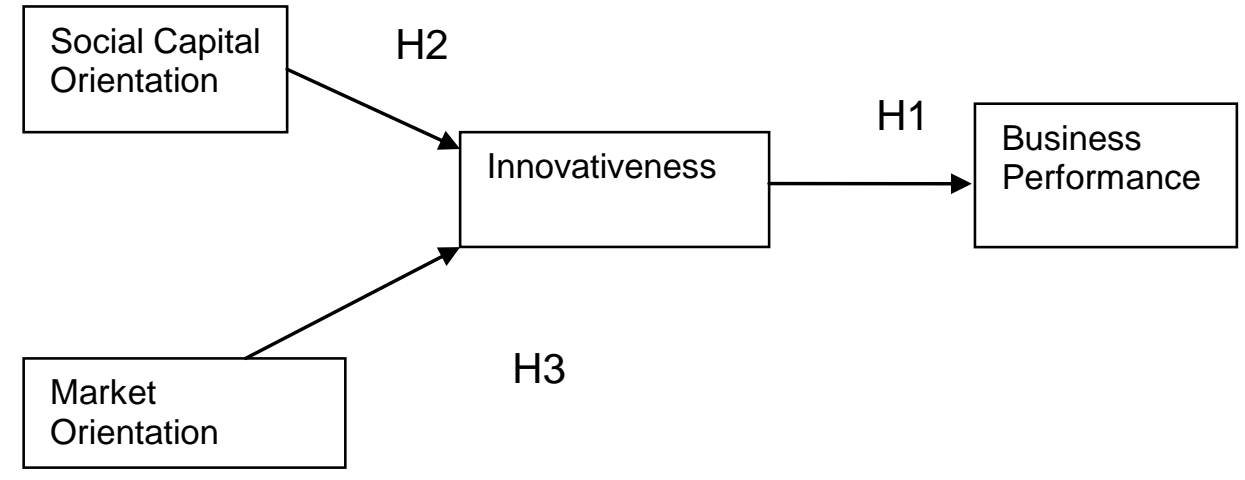

\section{The Methodology and Model}

The sampling frame of 1200 SMEs with an investment between $\$ 0.5$ to $\$ 1.5$ million in accordance with the definition of World Bank and Government of Bangladesh was drawn from the membership list of respective associations. The owners/ managers were used as key informants in assessing all the constructs described above, an approach applied in numerous studies (e.g., Gatignon \& Xuereb, 1997; Moorman \& Miner, 1997; Han et al., 1998) and follows Huber and Power's (1985) guidelines on how to get quality data from single informants.

Following the completion of a pre-test with eight academics and seven owners/managers of SMEs and a pilot study of 50 respondents to assess the quality of the research design, 1200 questionnaires were mailed along with preaddressed postage-paid envelopes and a cover letter explaining the purpose of the study and the confidentiality of responses. This procedure resulted in the return of 321 completed, usable questionnaires; a response rate of just over $26 \%$ after accounting for undeliverable surveys.

After data collection, the measures were subjected to a purification process involving a series of reliability and validity assessments in confirmatory factor analysis (CFA) models (exogenous and endogenous factors) using AMOS 5.

All purified measures were seven-point Likert scales anchored by "strongly disagree" and "strongly agree." To measure market orientation, we used the scale of Narver and Slater (1990) that, following purification, consisted of 15 items and assessed the sub-factors of competitor orientation, customer orientation, and internal operations. Innovativeness was quantified using the 16 item scale from Fritz, 1996; Pennings, 1991; Manu and Sriram, 1996; Baker and Sinkula, 1999. The scale for performance assessed profitability, growth in sales, and market share, as well as general performance and, following purification, consisted of five items.

Hypotheses were tested by the following procedures. First, a structural equation modeling technique was applied to examine the construct validity of all the factors appeared in the model. Second, hypothesis referring to relationship among social capital orientation, market orientation, entrepreneurial orientation, innovativeness and business performance were tested via the path analysis conducted with AMOS 5. 


\section{Hoq \& Chowdhury}

\section{Findings}

Structural Equation Modelling (SEM) model was developed and tested in the analyses for each of $\mathrm{H} 1-\mathrm{H} 4$. The model provided in a good fit to the data ( $\mathrm{v} 2=360.79, \mathrm{df}=10, \mathrm{D} 2=.94$, $\mathrm{RNI}=.94, \mathrm{CFI}=.94, \mathrm{RMSR}=.075, \mathrm{RMSEA}=.19, \mathrm{NCP}=19.96, \mathrm{ECVI}=0.27$ ) and all hypothesized relationships were supported. Specifically, with regard to $\mathrm{H} 1$, innovativeness is positively related to business performance $(0.35, \mathrm{P}<.01)$. Concerning $\mathrm{H} 2$, social capital orientation is positively related to innovativeness $(0.22, \mathrm{P}<.01)$. In support of $\mathrm{H} 3$, market orientation is positively related to innovativeness $(0.65, \mathrm{P}<.01)$. Moreover, entrepreneurial orientation is positively related to innovativeness, supporting $\mathrm{H} 4(0.31, \mathrm{P}<$ $.01)$.

Table 1: Summary of the AMOS Model

\begin{tabular}{|c|c|c|}
\hline Paths & Standardized path coefficient & Hypotheses \\
\hline $\begin{array}{l}\text { Innovat } \longrightarrow \text { Perf. } \\
\mathrm{SC} \quad \longrightarrow \text { Innovat } \\
\mathrm{MO} \longrightarrow \text { Innovat }\end{array}$ & $\begin{array}{l}0.35^{\star *} \\
0.22^{\star *} \\
0.65^{\star *}\end{array}$ & $\begin{array}{l}\text { H1: Supported } \\
\text { H2: Supported } \\
\text { H3: Supported }\end{array}$ \\
\hline Indices & Value & Recommended level \\
\hline GFI & 0.90 & $>0.90$ \\
\hline CFI & 0.89 & $>0.90$ \\
\hline RMSEA & 0.08 & $<0.08$ \\
\hline
\end{tabular}

Lastly, to provide further understanding of the relationships among the constructs, in Fig. 2 we report on the total (standardized) effects of all the antecedent constructs on business performance. The strongest overall drivers of performance, as portrayed here, are market orientation and innovativeness. This implies that innovativeness partially mediates the relationship between market orientation and performance On the other hand, the direct effect of social capital orientation on performance in Fig. 2 is insignificant, suggesting that social capital orientation must be mediated by some other construct, such as innovativeness, in order to have an effect on business performance.

Fig. 2: Total (standardized) effects on business performance. All coefficients are standardized and significant at $p<0.01$.

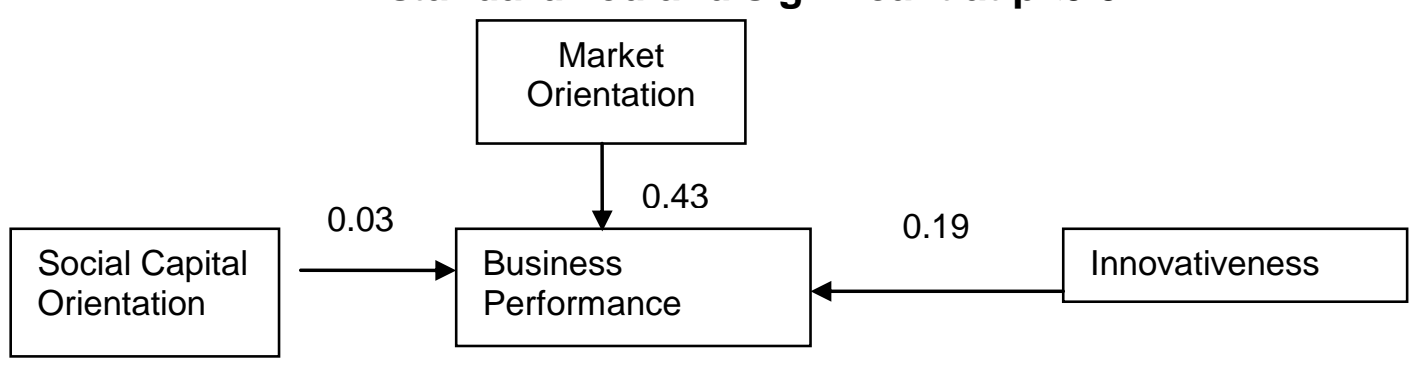

\section{Discussion \& Conclusion}

Our study addresses the impact of innovativeness on performance and key antecedents to innovativeness in a comprehensive, empirically verified model. We thereby fill a significant gap in understanding innovativeness, the nature of relationships between innovativeness and key variables that drive it and the effect of innovativeness on organizational performance. Several contributions to various research streams are noteworthy. First, our findings highlight the importance of a more integrated and compositional approach to the study of the effect of innovativeness and antecedent 


\section{Hoq \& Chowdhury}

orientations on business performance. This approach may be more fruitful and realistic than previous approaches of examining bivariate relationships between each of the constructs separately.

Next, empirical findings confirm innovativeness as an important determinant of business performance. This implies that innovative activities are generally important to the success of the SMEs. Accordingly, managers are advised to improve the innovativeness of their businesses in their efforts to attain superior business performance. These results, however, should be interpreted within the scope of this study and the measures used.

As a further contribution, the results imply that innovativeness at least partially mediates the respective relationships among market orientation and business performance. Indeed, the findings indicated in Fig. 2 suggest that social capital orientation has no significant direct effect on performance. These findings further underscore the role of innovativeness in organizational performance. Moreover, to the extent innovativeness is enhanced through the presence of the antecedent orientations highlighted here, firms should be able to create ever superior products, an outcome likely to increase market shares and other performance outcomes, particularly when compared to producers with less developed innovative practices.

Innovativeness is also likely to be useful for allowing the firm to pre-empt competitors with new or improved products, diversify product lines, and generally expand the firm's scope of activities. All of these outcomes can help contribute to achieve sustainable competitive advantage.

In general, evidence from this study underscores the importance of managerial emphasis on the creation of an internal business environment conducive to innovative activities. Specifically, market orientation was found to have a significant and positive effect on innovativeness. In the direct effects model (Fig. 2), market orientation appears to be the most important overall determinant of business performance. Given that market orientation helps managers to be more connected to the business environment, such an orientation appears to play a role for allowing the SMEs to devise innovative solutions to business problems. Having a market orientation may be more important when market composition and preferences are changing rapidly because such conditions may force the firm to modify its products and services more often than when it operates in a stable market.

Furthermore, findings generally suggest that when members of an organization acquire knowledge through social network, that organization acquires the ability to be innovative. It is consistent with the work of Cohen and Levinthal (1990), which indicates that the absorptive capacity of the firm is linked to the absorptive capacity of the people in the firm. More remarkably, as portrayed in the direct effects model (Fig. 2), the direct effect of social capital orientation in the presence of the other antecedents investigated here is insignificant. This implies that while innovativeness is an important direct driver of performance, it also appears to be a necessary mediator of the link between social capital orientation and performance. That is, without a strong innovative capability, social capital orientation may provide little or no value to achieve the performance objectives. Innovativeness supported by a market orientation and a social capital orientation in particular is likely to be more effective, generating additional competitive advantages because of the benefits that these antecedent constructs provide. That is, firms that are market and social capital oriented will tend to be more in touch with buyers and 


\section{Hoq \& Chowdhury}

understand their markets better, advantages that in turn should translate into innovative activities that give rise to superior products, processes, and administrative approaches.

Overall, the findings imply that market orientation and social capital orientation may help managers to devise superior products, processes, and ideas.

In conclusion, our findings point to several critical factors in the business performance of SMEs. In the aggregate, little is known about the interrelationships among the integrative elements of market orientation, social capital orientation, and their effect on innovativeness as well as the subsequent effect of innovativeness on business performance. Yet, the evidence introduced here implies that such interrelationships serve to provide sustained advantage to organizations and are therefore important to understand. Innovativeness, in particular, appears to be a key mediator in the web of relationships among the constructs.

Under such conditions, organizations are advised to invest in developing their market and social capital orientations. Additionally, the management should plan and implement innovative activities within the framework of these antecedent constructs. A central message from the evidence provided is that possession of a strong social capital orientation in the absence of organizational innovativeness is likely to be substantially less effective for allowing the firm to achieve its performance goals.

If innovativeness is important for organizational performance, the task for the management is to design and implement an organizational culture that embodies market and social capital orientations. To enhance business performance, it is imperative that an organizational structure be devised in which these often discrete areas be integrated within a coordinated framework to ensure that innovative activities reap the benefits that market orientation and social capital orientation can afford. We hope that our findings lead to improved managerial practices and future research that delves more deeply into these constructs and their interrelationships in a variety of settings among firms.

\section{References}

Abratt, R \& Lombard, A 1993, 'Determinants of product innovation in specialty chemical companies', Industrial Marketing Management, vol. 22, no. 3, pp. 169-176.

Anderson, J 1987, 'An approach for confirmatory measurement and structural equation modelling of organizational properties', Management Science, vol. 33 no. 4, pp. 525-541.

Anderson, JC \& Gerbing, DW 1982, 'Some methods for respecifying measurement models to obtain unidimensional construct measurement', Journal of Marketing Research, vol. 19, no. 2, pp. 453- 460.

Anderson, JC, \& Gerbing, DW 1988, 'Structural equation modelling in practice: A review and recommended two-step approach', Psychological Bulletin, vol. 103, no. 3, pp. 411- 423 .

Argyris, C \& Schon, DA 1978, Organizational learning: $A$ theory of action Perspective, $3^{\text {rd }}$ edn, Addition-Wesley, Reading.

Armstrong, JS \& Overton, TS 1977, 'Estimating nonresponse bias in mail Surveys', Journal of Marketing Research, vol.14, no. 3, pp. 396- 402.

Bagozzi, R \& Phillips, L 1982, 'Representing and testing organizational theories: A holistic construal', Administrative Science Quarterly, vol. 27, no. 2, pp. 459-489. 


\section{Hoq \& Chowdhury}

Bagozzi, RP \& Yi, Y 1988, 'On the evaluation of structural equation models', Journal of the Academy of Marketing Science, vol. 16, no. 3, pp. 74- 94.

Baker, WE \& Sinkula, JM 1999, 'The synergistic effect of market orientation and learning orientation on organizational performance' Journal of the Academy of Marketing Science, vol. 27 , no. 4 , pp. $411-427$.

Barney, J 1986, 'Organizational culture: Can it be a source of sustained competitive advantage?', Academy of Management Review, vol.11, no. 3, pp. 656- 665.

Bell, M \& Pavitt, K 1992, 'Accumulating technological capability', The World Bank Annual Conference on Development Economics. World Bank, New York, pp. 257-281

Bentler, P \& Cho, CP 1988, Practical issues in structural modelling. In J. Long (Ed.), Common problems/proper solutions: Avoiding error in quantitative research, Sage, Newbury Park, CA.

Bollen, K A 1989, Structural equations with latent variables. Wiley, New York.

Burns, T \& Stalker, G 196, The management of innovation, Tavistock Publications, London.

Calantone, RJ, Cavusgil, ST \& Zhao, Y 2002, 'Learning orientation, firm innovation, and firm performance', Industrial Marketing Management, vol. 31, no. 6, pp. 515- 524.

Cohen, MD \& Sproull, LS 1996, Organizational learning, Sage Publications, Thousand Oaks, CA.

Cohen, W \& Levinthal, D 1990, 'Absorptive capacity: A new perspective on learning and innovation', Administrative Science Quarterly, vol. 35, no. 2, pp. 128-152.

Cook, P 2001, 'Finance and Small and Medium-Sized Enterprise in Developing Countries', Journal of Developmental Entrepreneurship, Vol. 6 no. 1, pp. 45.

Cooper, AC \& Dunkelberg, WC 1986, 'Entrepreneurship and paths to business ownership', Strategic Management Journal, vol. 7, no. 1, pp. 53-68.

Cooper, AC, Woo, CY \& Dunkelberg, WC 1989, Entrepreneurship and the initial size of the firm. Journal of Business Venturing, vol. 7, no. 3, pp. 317-332.

Covin, J \& Slevin, D 1989, 'Strategic management of small firms in hostile and benign environments', Strategic Management Journal, vol. 10, no. 1, pp. 75-87.

Crossan, MM, Lane, HW, \& White, RE 1999, ' An organizational learning framework: From intuition to institution', Academy of Management Review, vol. 24, no. 4, pp. 522537.

Damanpour, F 1991, 'Organizational innovation: A meta-analysis of ef- fects of determinants and moderators', Academy of Management Journal, vol. 34, no. 3, pp. $555-590$.

Day, GS 1994, 'The capabilities of market-driven organizations', Journal of Marketing, vol. 58 , no. 1 , pp. 37- 52.

Deshpande, R, Farley, J \& Webster, F 1993, 'Corporate culture, customer orientation, and innovativeness in Japanese firms: A quadrad analysis', Journal of Marketing, vol. 57, no. 1 , pp. $23-37$.

Fiol, CM 1985, 'Organizational learning', Academy of Management Review, vol. 10, no. 4, pp. 803-813.

Fornell, C \& Larker, DF 1981, 'Evaluating structural equation models with unobservable variables and measurement errors', Journal of Marketing Research, vol. 18, no. 1, pp. 39- 50.

Fritz, W 1996 'Market orientation and corporate success: Findings from Germany', European Journal of Marketing, vol. 30, no. 8, pp. 59- 74.

Gatignon, H \& Xuereb, JM 1997, 'Strategic orientation of the firm and new product Performance', Journal of Marketing, vol. 34, no. 1, pp. 77- 90. 


\section{Hoq \& Chowdhury}

Gerbing, D \& Anderson, J 1992, 'Monte Carlo evaluations of goodness-of-fit indices for structural equation models', Sociological Methods and Research, vl. 21, no. 2, pp. 132- 160.

Greenley, G \& Foxall, G 1998, 'External moderation of associations among stakeholder orientations and company performance'. International Journal of Research in Marketing, vol. 15, no. 1, pp. 51-69.

Gadenne, D 1997, 'Critical Success Factors for Small Business: An Inter-Industry Comparison', International Small Business Journal, VI. 17, no. 1, pp. 36- 55.

Geraldo, VP 1992, 'Small and Medium-Sized Enterprises and Labour Law, International Labour Review, VI. 131, no. 6, pp 102-111.

Day, J 2000, 'The Value and Importance of Small Firm to the World Economy', European Journal of Marketing, vl.34 Issue 9/10.

Reynolds, DP 1997. 'New and Small Firms in Expanding Markets', Small Business Economics, VI. 9, no. 1, pp. 79-84.

Wang, Y \& Yao, Y 2002, 'Market Reforms, Technological Capabilities and the Performance of Small Enterprises in China', Small Business Economics, VI.18, no. 2, pp. 195-209.

Jones, O, Tilley, F. (Eds.) 2003, Competitive Advantage in SMEs: organizing for innovation and change, Wiley, Chichester.

Hutton, W 1995, The State Were In, Jonathan Cape, London.

Clark, PA, Staunton, N 1989, Innovation in Technology and Organization, Routledge, London

Drazin, R, Schoonhoven, CB 1996, 'Community population and organization effects on innovation: a multilevel perspective', Academy of Management Journal, vol. 39, no. 5, pp. 1065-1083.

SBS 2001, Small and medium-sized enterprise (SME) statistics for the UK, Small Business Service, press release.

Malecki, EJ 1997, Technology, and economic development: Local regional and national competitiveness (2nd ed.), Longman Press, Harlow.

Mytelka, LK 1993, 'Rethinking development: a role for innovation networking in the 'other two-thirds', Futures, vol. 25, no. 6, pp. 694-712.

Powell, WW 1990, 'Neither market or hierarchy: network forms of organization', Research in Organizational Behaviour, vol. 12, no. 3, pp. 295-336.

Storper, M \& Salais, RS 1997, Worlds of production: The action frameworks of the Economy, Harvard University Press, Cambridge.

Lee, C, Lee, K \& Pennings, JM 2001, 'Internal capabilities, external networks, and performance: a study on technology-based ventures', Strategic management Journal, vl. 22, no. 5, pp. 615-640.

P. Maskell, 2001, Social capital, innovation and competitiveness, in: S. Baron, J. Field, T. Schuller (Eds.), Social Capital: Critical Perspectives, Oxford Univ. Press, Oxford.

Merlo, O, Bell, SJ \& Whitwell, GJ 2006, 'Social capital, customer service orientation and creativity in retail stores', Journal of Business research, vol. 59, no. 12, pp. 12141221.

Greenley, G \& Oktemgil, M 1997, 'An investigation of modular effects on alignments Kill', Journal of Business Research, vl. 39, no. 2, pp. 93-105.

Han, J, Kim, N \& Srivastava, R 1998, 'Market orientation and organizational performance: Is innovation a missing link?', Journal of Marketing, vl.62, no. 4, pp. 30-45.

Henard, DH \& Szymanski, DM 2001, 'Why some new products are more successful than Others', Journal of Marketing Research, vl. 38, no. 3, pp. 362- 375.

Huber, GP 1991, 'Organizational learning: The contributing processes and the literatures', Organization Science, vl. 2, no. 1, pp. 88-115. 


\section{Hoq \& Chowdhury}

Huber, GP \& Power, DJ 1985, 'Retrospective reports of strategic- level managers:

Guidelines for increasing their accuracy', Strategic Management Journal, vl. 6, no. 1, pp. 171- 180.

Hult, GT 1998, 'Managing the international strategic sourcing function as a market-driven organizational learning system', Decision Sciences, vl. 29, no. 1, pp. 193- 216.

Hurley, R \& Hult, GT 1998, 'Innovation, market orientation, and organizational learning: An integration and empirical examination', Journal of Marketing, vl. 62, no. 1, pp. 4254.

Jaworski, B \& Kohli, A 1993, 'Market orientation: Antecedents and consequences', Journal of Marketing, vl. 57, no. 1, pp. 53-70.

Khandwalla, P 1977, The design of organizations. Harcourt Brace, New York

Kohli, A \& Jaworski, B 1990, 'Market orientation: The construct, research propositions, and managerial implications', Journal of Marketing, vl. 54, no. 1, pp. $1-18$.

Kohli, A, Jaworski, B \& Kumar, A 1993, 'Markor: A measure of marketing orientation. Journal of Marketing Research, vl. 30, no. 4, pp. 467-477.

Langerak, F, Peelen, E \& Commandeur, H 1997, 'Organizing for effective new product development', Industrial Marketing Management, vl. 26, no. 3, pp. 281-289.

Lumpkin, GT \& Dess, G 1996, 'Clarifying the entrepreneurial orientation construct and linking it to performance', Academy of Management Review, vl. 21, no. 1, pp. 135172.

McDonald, RP \& Marsh, HW 1990, 'Choosing a multivariate model: Noncentrality and goodness of fit', Psychological Bulletin, vl. 107, no. 2, pp. 247- 255.

Miller, D 1983, 'The correlates of entrepreneurship in three types of firms', Management Science, vl. 29, no. 7, pp. 770-791.

Miller, D 1987, 'The structural and environmental correlates of business strategy', Strategic Management Journal, vl. 8, no. 1, pp. 55- 76.

Miller, D \& Friesen, P 1978, 'Archetypes of strategy formulation', Management Science, vl. 24, no. 9, pp. 921-933.

Mintzberg, H 1973, The nature of managerial work. Harper \& Row, New York.

Moorman, C \& Miner, A 1997, 'The impact of organizational memory on new product performance and creativity', Journal of Marketing Research, vl. 24, no. 1, pp. 91106.

Moorman, C \& Miner, A 1998, 'The convergence of planning and execution: Improvisation in new product development', Journal of Marketing, vl. 62, no. 1, pp. $1-20$.

Naman, JL \& Slevin, DP 1993, 'Entrepreneurship and the concept of fit: A model and empirical tests. Strategic Management Journal', vl.14, no. 1, pp. 137-154.

Narver, J, \& Slater, S 1990, 'The effect of a market orientation on business profitability', Journal of Marketing, vl. 54, no. 4, pp. 20-35.

Narver, J, Slater, S \& Tietje, B 1998, 'Creating a market orientation. Journal of MarketFocused Management', vl.2, no.3, pp. 241- 256.

Oczkowski, E \& Farrell, M 1998, 'Discriminating between measurement scales using non-nested tests and two-stage least squares: The case of market orientation', International Journal of Research in Marketing, vl. 15, no. 4, pp. 349-366.

Poolton, J \& Barclay, I 1998, 'New product development from past research to future Applications', Industrial Marketing Management, vl. 27, no.3, pp. 197-212.

Porter, ME 1990, 'The competitive advantage of nations'. Harvard Business Review, vl. 68 , no. 1 , pp. $73-93$.

Schumpeter, J 1934, The theory of economic development, Cambridge University Press, Cambridge,

Sinkula, J 1994, ' Market information processing and organizational learning', Journal of Marketing, vl. 58, no. 1, pp. 35- 45. 


\section{Hoq \& Chowdhury}

Sinkula, J, Baker, W, \& Noordewier, T 1997, ' A framework for market- based organizational learning: Linking values, knowledge, and behaviour', Journal of the Academy of Marketing Science, vl. 25, no. 4, pp. 305-318.

Slater, S \& Narver, J 1993, 'Product-market strategy and performance: An analysis of the miles and snow strategy types', European Journal of Marketing, vl. 27, no. 10, pp. $33-51$.

Slater, S, \& Narver, J 1994a, 'Does competitive environment moderate the market orientation-performance relationship?', Journal of Marketing, vl. 58, no. 1, pp. 4655.

Slater, S, \& Narver, J 1994b, Market oriented isn't enough: Build a learning Organization, Marketing Science Institute, Cambridge.

Slater, S, \& Narver, J 1995, 'Market orientation and the learning organization', Journal of Marketing, vl. 59, no. 1, pp. 63-74.

Van de Ven, A H 1986, 'Central problems in the management of innovation', Management Science, vl. 32, no. 5, pp. 590- 607.

Wernerfelt, B 1984, 'A resource-based view of the firm', Strategic Management Journal, Vol. 5, no. 2, pp. 171-180.

Wijewardena, H \& Tibbits, GE 1999, 'Factors Contributing to the Growth of Small Manufacturing Firms: Data from Australia', Journal of Small Business Management, vl. 12, no. 4, pp. 332-349.

Zaltman, G, Duncan, R \& Holbek, J 1973, Innovations and organizations, Wiley, New York. 